Pak. j. sci. ind. res. Ser. B: biol. sci. 2017 60(3) 125-131

\title{
Response of Potato Cultivars to Organic and Inorganic Fertilizers Under the Agroclimatic Conditions of Skardu (Gilgit-Baltistan)
}

\author{
Syed Zahid Hussain ${ }^{a *}$, Ehsan Elahi ${ }^{\mathrm{b}}$, Nasrullah ${ }^{\mathrm{c}}$, Saeed Ahmed ${ }^{\mathrm{d}}$, Nazeer Ahmed ${ }^{\mathrm{e}}$ and Zelle Huma ${ }^{\mathrm{f}}$ \\ ${ }^{a}$ Agha Khan Rural Support Programme, Skardu, (AKRSP), Pakistan \\ ${ }^{b}$ Department of Horticulture, The University of Agriculture Peshawar, Pakistan \\ ${ }^{\mathrm{c}}$ Department of Agriculture, Ghanche Agriculture Department, Gilgit-Baltistan, Pakistan \\ ${ }^{\mathrm{d}}$ Centre of Agriculture Sciences, State University of Londrina, Londrina, Parana, (PR), Brazil \\ ${ }^{\mathrm{e} K e y ~ L a b o r a t o r y ~ o f ~ A p p l i e d ~ E n t o m o l o g y, ~ C o l l e g e ~ o f ~ P l a n t ~ P r o t e c t i o n, ~ N o r t h w e s t ~ A \& F ~ U n i v e r s i t y, ~ Y a n g l i n g, ~ C h i n a ~}$ \\ fDepartment of Plant Protection, University of Agriculture, Peshawar, Pakistan
}

(received February 17, 2016; revised October 27, 2016; accepted October 31, 2016)

\begin{abstract}
Field research was conducted during summer season in 2010, in order to determine the effective combination between potato varieties i.e., the best yielding potato cultivar under organic or inorganic fertilizer in Skardu valley, Gilgit-Baltistan, Pakistan. A randomized complete block design (RCBD) was used for the trial and both the experimental factors (cultivar and fertilizer type) significantly affected the crops growth and yield variables. Among the nine different organic and inorganic fertilizer treatments, the maximum mean values of sprouting rate $43.1 \%$, plant height $49.5 \mathrm{~cm}$, number of tubers/plant (8.5), weight of tubers/plant (385.9 g), tuber diameter $3.8 \mathrm{~cm}$ and yield $(25.7 \mathrm{t} / \mathrm{ha})$ were obtained in the crops which received 10 tonnes FYM/ha $+150 \mathrm{~kg} \mathrm{~N} / \mathrm{ha}$. Among the cultivars tested, Desiree showed the maximum mean values of sprouting rate $30.4 \%$, plant height $36.7 \mathrm{~cm}$, number of tubers/plant 7.3 , weight of tubers/plant $350.3 \mathrm{~g}$, tuber diameter $3.7 \mathrm{~cm}$ and yield $23.4 \mathrm{t} / \mathrm{ha}$. Overall results revealed that the treatment matched to $10 \mathrm{t} / \mathrm{ha} \mathrm{FYM}+150 \mathrm{~kg} / \mathrm{ha} \mathrm{N}$ (T7) led to the highest tuber yield and Desiree showed better performances than other cultivars.
\end{abstract}

Keywords: potato cultivars, fertilizer levels, yield, Skardu

\section{Introduction}

In Gilgit-Baltistan (Pakistan), agriculture is the mainstay of the people living in the area, as more than $90 \%$ of the population depends upon agriculture (Alam et al., 2007). The climate is ideally suited for the cultivation of potato, but the productivity of this crop is very low despite the high labour employment. In fact, potato yield per ha is lower than that obtained in the rest of the country 17.7 vs 23.6 tonnes, respectively.

Total area devoted to potato cultivation in Gilgit-Baltistan was 6483 ha in 2005 MINFAL (2005). Notably, in 1950 two varieties, Katwar Red and Phulwar White, were mainly grown there, whereas after 1955-56 another variety named Ultimas was approved for cultivation and it is still grown in Skardu, Gilgit and the surrounding areas (FAO, 2010). Currently, the most famous cultivars grown in Gilgit-Baltistan are Desiree, Cardinal, Ultimus (red) and Diamond (white).

Unfortunately, in Pakistan fertilizers are very expensive and sometimes not available by the dealers hence, the

*Author for correspondence; E-mail: zahid_skd@yahoo.com farmers fail to apply the inorganic fertilizers to crops at an appropriate time and accordingly, they are not able to manage the crops properly. In this scenario, organic manure is being used by farmers' community as a source of plant nutrients which is easily available to the farmers and cheaper, as compared to inorganic fertilizers. Notably, organic fertilizers such as cattle manure, poultry manure and green manure include high quantity of nutrients which influence plant growth and yield, by improving biological, chemical, and physical fertility of the soil (Benke et al., 2009). Moreover, in previous research (Caruso et al., 2013) potato crops grown under organic nutrition showed yield and quality performances comparable with those usually obtained under mineral fertilization. The present study was designed to assess the combined effect of organic and inorganic fertilizers on the yield of different potato cultivars in the climatic conditions of Skardu (GilgitBaltistan).

\section{Materials and Methods}

A research was conducted on potato (Solanum tuberosum L.) at the Agriculture Research Station Skardu (Gilgit- 
Baltistan) in 2010. A randomized complete block design, with three replicates was arranged in order to compare twenty-seven treatments obtained from the combination of two experimental factors, cultivar and fertilizer type. Notably, the cultivar was applied at three levels, using three red skinned genotypes: Desiree, Cardinal and Ultimus. Fertilizer type was tested with nine levels: T1 $=$ no fertilized control; $\mathrm{T} 2=10 \mathrm{t} / \mathrm{ha}$ farmyard manure $(\mathrm{FYM}) ; \mathrm{T} 3=20 \mathrm{t} / \mathrm{ha} \mathrm{FYM}$; T4 $=75 \mathrm{~kg} / \mathrm{ha}$ of mineral nitrogen $(\mathrm{N}) ; \mathrm{T} 5=150 \mathrm{~kg} / \mathrm{ha} \mathrm{N}$; T6 $=10$ tonnes $/ \mathrm{ha}$ $\mathrm{FYM}+75 \mathrm{~kg} / \mathrm{ha} \mathrm{N} ; \mathrm{T} 7=10 \mathrm{t} / \mathrm{ha} \mathrm{FYM}+150 \mathrm{~kg} / \mathrm{ha} \mathrm{N}$; $\mathrm{T} 8=20 \mathrm{t} / \mathrm{ha} \mathrm{FYM}+75 \mathrm{~kg} / \mathrm{ha} \mathrm{N}$; T9 = $20 \mathrm{t} / \mathrm{ha} \mathrm{FYM} \mathrm{+}$ $150 \mathrm{~kg} / \mathrm{ha} \mathrm{N}$.

Organic mature farmyard manure (FYM) was applied before planting, while nitrogen was applied in two split doses, the first one before planting and the second one concurrently with the first earthing up.

Data collection. Determinations were performed on five randomly selected plants, regarding the following variables: sprouting percentage, plant height $(\mathrm{cm})$, number of tubers per plant, weight of tubers per plant $(\mathrm{g})$, diameter of tubers $(\mathrm{cm})$, and yield per ha (tonnes).

Statistical analysis. Data were statistically processed by analysis of variance and the mean separations were performed through the Duncan multiple range test and the LSD test, with reference to 0.01 and 0.05 probability levels, using a statistical package MSTATC (Steel et al., 1997). Data expressed as percentage were subjected to angular transformation before processing.

\section{Results and Discussion}

The present study was conducted to determine the response of potato cultivars to organic and inorganic fertilizers under the agroclimatic conditions of Skardu (Gilgit-Baltistan).

Sprouting rate. Data regarding sprouting percentage were statistically analyzed (Table 1). The results demonstrated that maximum sprouting was $30.4 \%$ in Desiree while minimum $19.3 \%$ was found in Ultimus. As for fertilizers, the best sprouting response was recorded with T5 (43.1\%), where inorganic fertilizer was applied at $150 \mathrm{~kg} / \mathrm{ha}$ nitrogen, while the poorest sprouting was recorded with T3 (8.2\%), where Farmyard manure (FYM) was applied at 20 tonnes/ha. Nitrogen is very essential for plant growth because it is a main constituent of amino acid, proteins, nucleic acid, some hormones and chlorophyll, which are all important for healthy plant growth (Hopkins, 1997). In this respect, maximum
Table 1. Effects of cultivar and fertilizer type on sprouting rate

\begin{tabular}{ll}
\hline \hline Treatment & Sprouting (\%) \\
\hline Cultivar & \\
$\quad$ Desiree & $30.4 \mathrm{a}$ \\
Cardinal & $23.4 \mathrm{~b}$ \\
Ultimus & $19.3 \mathrm{c}$ \\
Fertilizer type & \\
T1 (control) & $19.4 \mathrm{f}$ \\
T2 $=10$ tonnes $/ \mathrm{ha}(\mathrm{FYM})$ & $11.4 \mathrm{~g}$ \\
$\mathrm{~T} 3=20$ tonnes $/ \mathrm{ha}(\mathrm{FYM})$ & $8.2 \mathrm{~h}$ \\
$\mathrm{~T} 4=75 \mathrm{~kg}$ nitrogen $/ \mathrm{ha}$ & $23.2 \mathrm{e}$ \\
$\mathrm{T} 5=150 \mathrm{~kg}$ nitrogen $/ \mathrm{ha}$ & $43.1 \mathrm{a}$ \\
$\mathrm{T} 6=10 \mathrm{t} / \mathrm{h}(\mathrm{FYM})+75 \mathrm{~kg} \mathrm{~N} / \mathrm{ha}$ & $22.3 \mathrm{e}$ \\
$\mathrm{T} 7=10 \mathrm{t} / \mathrm{h}(\mathrm{FYM})+150 \mathrm{~kg} \mathrm{~N} / \mathrm{ha}$ & $26.4 \mathrm{~d}$ \\
$\mathrm{~T} 8=20$ tonnes $/ \mathrm{ha}(\mathrm{FYM})+75 \mathrm{~kg} \mathrm{~N} / \mathrm{ha}$ & $33.6 \mathrm{~b}$ \\
T9=20 tonnes$/ \mathrm{ha}(\mathrm{FYM})+150 \mathrm{~kg} \mathrm{~N} / \mathrm{ha}$ & $31.6 \mathrm{c}$ \\
\hline \hline
\end{tabular}

Means followed by different letters are significantly different according to Duncan multiple range test with reference to 0.05 probability level.

sprouting percentage was obtained with $\mathrm{T} 5$, where inorganic fertilizer was applied at $150 \mathrm{~kg} / \mathrm{ha}$ nitrogen, which showed that mineral $\mathrm{N}$ was readily available for uptake and utilization, thus resulting in better sprouting percentage than the other treatments. Another possible reason could be that increased rate of $\mathrm{N}$ application enhanced the seed-tuber progress, which resulted in earlier completion of emergence process and, accordingly, higher sprouting percentage. Similar results were found by Akhtar et al. (2010), reporting that $\mathrm{N}$ enhanced the emergence percentage.

However, poor sprouting percentage in T3, where Farmyard manure (FYM) was applied at $20 \mathrm{t} / \mathrm{ha}$, was due to insufficient availability of N, presumably caused by the fact that organic fertilizer like FYM slowly releases nutrients for plants uptake (Gruber et al., 2003; Delden, 2001).

Plant height. Data statistical analysis regarding plant heights showed that both cultivar and fertilizer type significantly affected the plant height. As reported in Table 2 the maximum average plant height was recorded in Desiree $(36.7 \mathrm{~cm})$ and the minimum in Cardinal (26.6 $\mathrm{cm})$. As for fertilizer type, T5 and T1 resulted in the best and worst effect (49.5 and $22.4 \mathrm{~cm}$ ), respectively.

Potato plant growth is significantly affected by the application of nitrogen (Blumenthal et al., 2004; AbouHussein, 2003; Joern and Vitosh, 1995). The maximum 
Table 2. Effects of cultivar and fertilizer type on plant height

\begin{tabular}{|c|c|}
\hline Treatment & Plant height $(\mathrm{cm})$ \\
\hline \multicolumn{2}{|l|}{ Cultivar } \\
\hline Desiree & $36.7 \mathrm{a}$ \\
\hline Cardinal & $26.6 \mathrm{c}$ \\
\hline Ultimus & $33.2 \mathrm{~b}$ \\
\hline \multicolumn{2}{|l|}{ Fertilizer type } \\
\hline T1 (control) & $22.4 \mathrm{f}$ \\
\hline $\mathrm{T} 2=10$ tonnes/ha $(\mathrm{FYM})$ & $23.1 \mathrm{ef}$ \\
\hline $\mathrm{T} 3=20$ tonnes/ha $(\mathrm{FYM})$ & $29.1 \mathrm{~d}$ \\
\hline $\mathrm{T} 4=75 \mathrm{~kg}$ nitrogen $/ \mathrm{ha}$ & $34.2 \mathrm{c}$ \\
\hline $\mathrm{T} 5=150 \mathrm{~kg}$ nitrogen $/ \mathrm{ha}$ & $49.5 \mathrm{a}$ \\
\hline $\mathrm{T} 6=10 \mathrm{t} / \mathrm{h}(\mathrm{FYM})+75 \mathrm{~kg} \mathrm{~N} / \mathrm{ha}$ & $24.8 \mathrm{e}$ \\
\hline $\mathrm{T} 7=10 \mathrm{t} / \mathrm{h}(\mathrm{FYM})+150 \mathrm{~kg} \mathrm{~N} / \mathrm{ha}$ & $41.4 \mathrm{~b}$ \\
\hline $\mathrm{T} 8=20$ tonnes $/ \mathrm{ha}(\mathrm{FYM})+75 \mathrm{~kg} \mathrm{~N} / \mathrm{ha}$ & $34.9 \mathrm{c}$ \\
\hline $\mathrm{T} 9=20$ tonnes $/ \mathrm{ha}(\mathrm{FYM})+150 \mathrm{~kg} \mathrm{~N} / \mathrm{ha}$ & $30.1 \mathrm{~d}$ \\
\hline
\end{tabular}

Means followed by different letters are significantly different according to Duncan multiple range test with reference to 0.05 probability level.

plant height was observed in T5, where the $150 \mathrm{~kg} / \mathrm{N} / \mathrm{ha}$ application might have resulted in prompt mineral $\mathrm{N}$ uptake and utilization, accordingly leading to enhanced plant height as compared to the other treatments. The minimum plant height in $\mathrm{T} 1$, where no fertilizer was applied, might be due to the poor soil fertility status for plant growth. However, reverse result was found by Rehman (1996), as the combined application of organic and inorganic fertilizers increased the plant height.

Furthermore, FYM has a capacity to supply macro as well as micronutrients slowly to the plants, which depends upon the rate of mineralization (Gruber et al., 2003; Delden, 2001). That might be the reason for better plant growth in inorganic $\mathrm{N}$ application than combined application with FYM as an organic fertilizer.

Number of tubers per plant. There were significant main and interactive effects of cultivars and fertilizer type on the number of tubers per plant (Tables 3-4). The effect of combined application of organic and inorganic fertilizers on average number of tubers per plant for different cultivars is reported in Table 4. The results demonstrated that the maximum average number of tubers per plant was 10.4 in Desiree while the minimum was 5.7 in Cardinal, at T7 and T1, respectively. However, the mean value of treatments showed that the best response was recorded with $\mathrm{T} 7$, where $10 \mathrm{t} / \mathrm{ha}$ $(\mathrm{FYM})+150 \mathrm{~kg} / \mathrm{ha} \mathrm{N}$, while T1 (no fertilizer) was applied resulted in poor tuber number per plant. Among cultivars, Desiree showed the most pronounced response to combined application of organic and inorganic fertilizers for average number of tubers per plant.

Proper plant growth conditions are essential for potato growth and tuber yield. It has been observed that a

Table 3. Effects of cultivar and fertilizer type on tuber number per plant

\begin{tabular}{ll}
\hline \hline Treatment & $\begin{array}{l}\text { Tuber number } \\
\text { per plant }\end{array}$ \\
\hline Cultivar & \\
Desiree & $7.3 \mathrm{a}$ \\
Cardinal & $6.5 \mathrm{~b}$ \\
Ultimus & $6.2 \mathrm{c}$ \\
Fertilizer type & \\
T1 (control) & $5.8 \mathrm{f}$ \\
T2 $=10$ tonnes/ha $(\mathrm{FYM})$ & $6.8 \mathrm{de}$ \\
T3=20 tonnes/ha $(\mathrm{FYM})$ & $7.1 \mathrm{~d}$ \\
$\mathrm{~T} 4=75 \mathrm{~kg}$ nitrogen $/ \mathrm{ha}$ & $6.6 \mathrm{e}$ \\
$\mathrm{T} 5=150 \mathrm{~kg}$ nitrogen $/ \mathrm{ha}$ & $6.6 \mathrm{e}$ \\
$\mathrm{T} 6=10 \mathrm{t} / \mathrm{h}(\mathrm{FYM})+75 \mathrm{~kg} \mathrm{~N} / \mathrm{ha}$ & $7.8 \mathrm{c}$ \\
$\mathrm{T} 7=10 \mathrm{t} / \mathrm{h}(\mathrm{FYM})+150 \mathrm{~kg} \mathrm{~N} / \mathrm{ha}$ & $8.5 \mathrm{a}$ \\
$\mathrm{T} 8=20$ tonnes/ha $(\mathrm{FYM})+75 \mathrm{~kg} \mathrm{~N} / \mathrm{ha}$ & $8.3 \mathrm{~b}$ \\
$\mathrm{~T} 9=20$ tonnes/ha $(\mathrm{FYM})+150 \mathrm{~kg} \mathrm{~N} / \mathrm{ha}$ & $7.7 \mathrm{c}$ \\
\hline \hline
\end{tabular}

Means followed by different letters are significantly different according to Duncan multiple range test with reference to 0.05 probability level.

Table 4. Interaction of cultivar and fertilizer type on tuber number per plant

\begin{tabular}{|c|c|c|c|}
\hline \multirow[t]{2}{*}{ Fertilizer type } & \multicolumn{3}{|c|}{ Cultivar } \\
\hline & Desiree & Cardinal & Ultimus \\
\hline T1 (control) & 5.9 & 5.7 & 6.3 \\
\hline $\mathrm{T} 2=10$ tonnes/ha $(\mathrm{FYM})$ & 7.6 & 6.2 & 6.6 \\
\hline T3=20 tonnes/ha (FYM) & 8.3 & 5.9 & 7.2 \\
\hline $\mathrm{T} 4=75 \mathrm{~kg}$ nitrogen $/ \mathrm{ha}$ & 6.9 & 6.3 & 6.7 \\
\hline $\mathrm{T} 5=150 \mathrm{~kg}$ nitrogen $/ \mathrm{ha}$ & 6.7 & 6.3 & 7.0 \\
\hline \multicolumn{4}{|l|}{$(\mathrm{FYM})+75 \mathrm{~kg} \mathrm{~N} / \mathrm{ha}$} \\
\hline $\begin{array}{l}\text { T7 }=10 \text { tonnes } / \mathrm{h} \\
\qquad(\mathrm{FYM})+150 \mathrm{~kg} \mathrm{~N} / \mathrm{ha}\end{array}$ & 10.4 & 7.1 & 8.0 \\
\hline $\begin{aligned} \mathrm{T} 8= & 20 \text { tonnes } / \mathrm{ha} \\
& (\mathrm{FYM})+75 \mathrm{~kg} \mathrm{~N} / \mathrm{ha}\end{aligned}$ & 9.9 & 7.7 & 7.5 \\
\hline $\begin{aligned} \mathrm{T} 9= & 20 \text { tonnes } / \mathrm{ha} \\
& (\mathrm{FYM})+150 \mathrm{~kg} \mathrm{~N} / \mathrm{ha}\end{aligned}$ & 8.7 & 7.4 & 6.9 \\
\hline \multicolumn{2}{|l|}{ LSD between cultivars } & \multicolumn{2}{|l|}{0.2} \\
\hline \multicolumn{2}{|c|}{ LSD between fertilizer types } & \multicolumn{2}{|l|}{0.4} \\
\hline
\end{tabular}


potato crop approximately takes up 3-5 kg nitrogen, 0.4-0.8 kg phosphorus and 4-6 kg potassium per ton of tubers (Allison et al., 1999; Perrenoud, 1983). According to Najm et al. (2010), nitrogen must be applied as organic or inorganic form in the soil for maximum growth and tuber yield. The number of tubers per plant in T8 (20 t/ha FYM $+75 \mathrm{~kg} / \mathrm{ha} \mathrm{N})$ reveals a significant positive effect of combined application of organic and inorganic fertilizers on tuber production. This is due to sustained supply of macro- as well as micronutrients through FYM and inorganic fertilizer (Chattopadhyay and Gupta, 1999). Moreover, combined applications also improve soil properties and make suitable plant growth conditions (Patra et al., 2000; Chand, 1999).

Tuber weight per plant. There were significant main and interactive effects of cultivar and fertilizer type on the tuber weight per plant (Tables 5-6). The mean value of treatments showed that the best response was recorded with T7 (10 t/ha FYM $+150 \mathrm{~kg}$ /ha N, while the minimum weight of tubers per plant was recorded with T1 (no fertilizer), as shown in Table 5. Moreover, the effect of combined application of organic and inorganic fertilizers on weight of tubers per plant for different cultivars is presented in Table 6. The results revealed that the maximum average weight of tubers per plant was $455.7 \mathrm{~g}$ in Desiree, while the minimum was $189.3 \mathrm{~g}$ in Cardinal, at T7 and T1, respectively. Among cultivars, Desiree showed the highest weight of tubers per plant under the combined application of organic and inorganic fertilizers.

A good response of potatoes to the fertilizer application is considered when it resulted in improved weight of tuber and increased yield. The data regarding weight of tubers per plant in $\mathrm{T} 7$ might be due to the proper availability of nutrients and soil conditions; indeed, combined application of $\mathrm{N}$ and FYM manure have presumably improved the nutrients status of soil, which resulted in higher tuber weight per plant. Abou-Hussein et al. (2003) demonstrated that the increase of soil nutrients can promote plant growth which enhances the photosynthetic and assimilation rates. Thus yield contributing components like size, weight and total yield increased. Tuku (2000) reported that higher yield was related to proper nutrients and water availability to the plant, in turn resulting in more tuber weight.

Tuber diameter. There were significant main and interactive effects of cultivar and fertilizer type on the diameter of large sized tubers (Tables 7-8). The mean
Table 5. Effects of cultivar and fertilizer type on tuber weight per plant

\begin{tabular}{|c|c|}
\hline Treatment & $\begin{array}{l}\text { Tuber weight } \\
\text { per plant }(\mathrm{g})\end{array}$ \\
\hline \multicolumn{2}{|l|}{ Cultivar } \\
\hline Desiree & $350.3 \mathrm{a}$ \\
\hline Cardinal & $260.4 \mathrm{c}$ \\
\hline Ultimus & $286.9 \mathrm{~b}$ \\
\hline \multicolumn{2}{|l|}{ Fertilizer type } \\
\hline T1 (control) & $221.0 \mathrm{f}$ \\
\hline $\mathrm{T} 2=10$ tonnes/ha $(\mathrm{FYM})$ & $229.4 \mathrm{f}$ \\
\hline $\mathrm{T} 3=20$ tonnes/ha $(\mathrm{FYM})$ & $292.9 \mathrm{e}$ \\
\hline $\mathrm{T} 4=75 \mathrm{~kg}$ nitrogen $/ \mathrm{ha}$ & $291.0 \mathrm{e}$ \\
\hline $\mathrm{T} 5=150 \mathrm{~kg}$ nitrogen $/ \mathrm{ha}$ & $352.1 \mathrm{~b}$ \\
\hline $\mathrm{T} 6=10$ tonnes $/ \mathrm{h}(\mathrm{FYM})+75 \mathrm{~kg} \mathrm{~N} / \mathrm{ha}$ & $283.7 \mathrm{e}$ \\
\hline $\mathrm{T} 7=10$ tonnes $/ \mathrm{h}(\mathrm{FYM})+150 \mathrm{~kg} \mathrm{~N} / \mathrm{ha}$ & $385.9 \mathrm{a}$ \\
\hline $\mathrm{T} 8=20$ tonnes $/ \mathrm{ha}(\mathrm{FYM})+75 \mathrm{~kg} \mathrm{~N} / \mathrm{ha}$ & $324.3 \mathrm{c}$ \\
\hline $\mathrm{T} 9=20$ tonnes $/ \mathrm{ha}(\mathrm{FYM})+150 \mathrm{~kg} \mathrm{~N} / \mathrm{ha}$ & $311.4 \mathrm{~d}$ \\
\hline
\end{tabular}

Means followed by different letters are significantly different according to Duncan multiple range test with reference to 0.05 probability level.

Table 6. Interaction between cultivar and fertilizer type on the weight of tubers per plant (g)

\begin{tabular}{|c|c|c|c|}
\hline \multirow[t]{2}{*}{ Fertilizer type } & \multicolumn{3}{|c|}{ Cultivar } \\
\hline & Desiree & Cardinal & Ultimus \\
\hline T1 (control) & 261.3 & 189.3 & 212.3 \\
\hline $\mathrm{T} 2=10$ tonnes/ha $(\mathrm{FYM})$ & 271.0 & 195.3 & 222.0 \\
\hline $\mathrm{T} 3=20$ tonnes $/$ ha $(\mathrm{FYM})$ & 345.0 & 251.0 & 282.7 \\
\hline $\mathrm{T} 4=75 \mathrm{~kg}$ nitrogen $/ \mathrm{ha}$ & 318.0 & 294.3 & 260.7 \\
\hline $\mathrm{T} 5=150 \mathrm{~kg}$ nitrogen $/ \mathrm{ha}$ & 415.7 & 301.3 & 339.3 \\
\hline $\begin{aligned} \mathrm{T} 6= & 10 \text { tonnes } / \mathrm{h} \\
& (\mathrm{FYM})+75 \mathrm{~kg} \mathrm{~N} / \mathrm{ha}\end{aligned}$ & 335.7 & 241.7 & 273.7 \\
\hline $\begin{aligned} \mathrm{T} 7= & 10 \text { tonnes } / \mathrm{h} \\
& (\mathrm{FYM})+150 \mathrm{~kg} \mathrm{~N} / \mathrm{ha}\end{aligned}$ & 455.7 & 328.7 & 373.3 \\
\hline $\begin{aligned} \mathrm{T} 8= & 20 \text { tonnes } / \mathrm{ha} \\
& (\mathrm{FYM})+75 \mathrm{~kg} \mathrm{~N} / \mathrm{ha}\end{aligned}$ & 383.0 & 275.0 & 315.0 \\
\hline $\begin{aligned} \mathrm{T} 9= & 20 \text { tonnes } / \mathrm{ha} \\
& (\mathrm{FYM})+150 \mathrm{~kg} \mathrm{~N} / \mathrm{ha}\end{aligned}$ & 367.3 & 263.7 & 303.3 \\
\hline LSD between cultivars & & 6.6 & \\
\hline LSD between fertilizer & & 11.4 & \\
\hline
\end{tabular}

value of treatments showed that the best response was recorded with T8 (20 t/ha FYM $+75 \mathrm{~kg} / \mathrm{ha})$, while T1 (no fertilizer) resulted in the poorest tuber diameter, as shown in Table 7. Moreover, the results demonstrated that the maximum diameters of large sized tubers was $4.49 \mathrm{~cm}$ in Desiree, while the minimum was $2.40 \mathrm{~cm}$ 
in Ultimus, at T8 and T1, respectively (Table 8). Furthermore, Desiree was the cultivar showing the most large sized tubers as a response to combined application of organic and inorganic fertilizers.

High nitrogen concentration tends to enhance cell division and cell number. In this respect, FYM supplies

Table 7. Effects of cultivar and fertilizer type on tuber diameter

\begin{tabular}{ll}
\hline \hline Treatment & $\begin{array}{l}\text { Tuber diameter } \\
(\mathrm{cm})\end{array}$ \\
\hline Cultivar & \\
Desiree & $3.73 \mathrm{a}$ \\
Cardinal & $3.40 \mathrm{~b}$ \\
Ultimus & $2.94 \mathrm{c}$ \\
Fertilizer type & \\
T1 (control) & $2.73 \mathrm{I}$ \\
T2=10 tonnes/ha (FYM) & $2.84 \mathrm{H}$ \\
T3=20 tonnes/ha (FYM) & $2.97 \mathrm{G}$ \\
T4=75 kg nitrogen/ha & $3.38 \mathrm{E}$ \\
T5=150 kg nitrogen/ha & $3.27 \mathrm{~F}$ \\
T6=10 tonnes/h $(\mathrm{FYM})+75 \mathrm{~kg} \mathrm{~N} / \mathrm{ha}$ & $3.52 \mathrm{D}$ \\
T7=10 tonnes/h $(\mathrm{FYM})+150 \mathrm{~kg} \mathrm{~N} / \mathrm{ha}$ & $3.79 \mathrm{~B}$ \\
T8=20 tonnes/ha $(\mathrm{FYM})+75 \mathrm{~kg} \mathrm{~N} / \mathrm{ha}$ & $4.02 \mathrm{~A}$ \\
T9=20 tonnes/ha (FYM) $+150 \mathrm{~kg} \mathrm{~N} / \mathrm{ha}$ & $3.70 \mathrm{C}$ \\
\hline \hline
\end{tabular}

Means followed by different letters are significantly different according to Duncan multiple range test with reference to 0.05 probability level.

Table 8. Interaction between cultivar and fertilizer type on tuber diameter $(\mathrm{cm})$

\begin{tabular}{llll}
\hline \hline Fertilizer type & \multicolumn{3}{c}{ Cultivar } \\
\cline { 2 - 4 } & Desiree & Cardinal & Ultimus \\
\hline T1 (control) & 3.03 & 2.75 & 2.40 \\
T2 $=10$ tonnes/ha (FYM) & 3.16 & 2.87 & 2.50 \\
T3=20 tonnes/ha (FYM) & 3.30 & 3.01 & 2.61 \\
T4=75 kg nitrogen/ha & 3.76 & 3.42 & 2.95 \\
T5=150 kg nitrogen/ha & 3.64 & 3.32 & 2.86 \\
T6=10 tonnes $/ \mathrm{h}$ & 3.91 & 3.57 & 3.09 \\
(FYM) $+75 \mathrm{~kg}$ N/ha & & & \\
T7=10 tonnes/h & 4.21 & 3.83 & 3.33 \\
(FYM) $+150 \mathrm{~kg}$ N/ha & & & \\
T8=20 tonnes/ha & 4.49 & 4.08 & 3.51 \\
(FYM) $+75 \mathrm{~kg}$ N/ha & & & \\
T9=20 tonnes/ha & 4.11 & 3.75 & 3.24 \\
(FYM) $+150 \mathrm{~kg}$ N/ha & & & \\
$\quad$ LSD between cultivars \\
$\quad$ & 0.07 & \\
$\quad$ LSD between fertilizer types & 0.43 & \\
\hline \hline
\end{tabular}

macro- as well as micronutrients and, accordingly, can fulfill the nutritional requirements of potato plants resulting in the tuber diameter increase. This might be the possible cause for greater tuber diameter in T8. Abou-Hussein et al. (2003) demonstrated that the increase of the soil nutrients can promote plant growth, by encouraging the photosynthetic and assimilation rates. Thus, yield contributing components like tuber size and weight increase. Conversely, the minimum tuber diameter might be related to the poor growing conditions. Consistent with our results, Rehman (1996) found that the application of organic and inorganic fertilizers increased the tuber diameter.

Tuber yield. Data regarding tuber yield per ha indicated that there were significant main and interactive effects of cultivar and fertilizer type (Tables 9-10). As for the fertilizer treatments, the highest production $(25.7 \mathrm{t} / \mathrm{ha})$ was recorded with T7 (10 t/ha FYM $+150 \mathrm{~kg} / \mathrm{ha} \mathrm{N})$, whereas T1 (no fertilized control) showed the minimum value (14.7 t/ha), as shown in Table 9. Moreover, the maximum tuber yield per ha was given by Desiree (30.4 $\mathrm{t} / \mathrm{ha}$ ), while the lowest level (12.6 t/ha) was detected in Cardinal, at T7 and T1, respectively (Table 10). Furthermore, Desiree showed the most enhanced response to combined application of organic and inorganic fertilizers (23.4 t/ha), followed by Ultimus and Cardinal.

Table 9. Effects of cultivar and fertilizer type on tuber yield per ha

\begin{tabular}{ll}
\hline \hline Treatment & $\begin{array}{l}\text { Tuber yield } \\
(\mathrm{t} / \mathrm{ha})\end{array}$ \\
\hline Cultivar & $23.4 \mathrm{a}$ \\
Desiree & $17.3 \mathrm{c}$ \\
Cardinal & $19.1 \mathrm{~b}$ \\
Ultimus & \\
Fertilizer type & $14.7 \mathrm{f}$ \\
T1 (control) & $15.3 \mathrm{f}$ \\
T2=10 tonnes/ha $(\mathrm{FYM})$ & $19.5 \mathrm{e}$ \\
T3=20 tonnes/ha $(\mathrm{FYM})$ & $19.4 \mathrm{e}$ \\
T4=75 kg nitrogen/ha & $23.5 \mathrm{~b}$ \\
T5=150 kg nitrogen/ha & $18.9 \mathrm{e}$ \\
T6=10 tonnes/h $(\mathrm{FYM})+75 \mathrm{~kg} \mathrm{~N} / \mathrm{ha}$ & $25.7 \mathrm{a}$ \\
T7=10 tonnes/h $(\mathrm{FYM})+150 \mathrm{~kg} \mathrm{~N} / \mathrm{ha}$ & $21.6 \mathrm{c}$ \\
T8=20 tonnes/ha $(\mathrm{FYM})+75 \mathrm{~kg} \mathrm{~N} / \mathrm{ha}$ & $20.8 \mathrm{~d}$ \\
T9=20 tonnes/ha $(\mathrm{FYM})+150 \mathrm{~kg} \mathrm{~N} / \mathrm{ha}$ \\
\hline \hline Means followed by different letters are significantly different \\
according to Duncan multiple range test with reference to \\
0.05 probability level.
\end{tabular}


Table 10. Interaction between cultivar and fertilizer type on tuber yield $(\mathrm{t} / \mathrm{ha})$

\begin{tabular}{llll}
\hline \hline Fertilizer type & \multicolumn{3}{c}{ Cultivar } \\
\cline { 2 - 4 } & Desiree & Cardinal & Ultimus \\
\hline T1 (control) & 17.4 & 12.6 & 14.2 \\
T2 =10 tonnes/ha (FYM) & 18.1 & 13.0 & 14.8 \\
T3=20 tonnes/ha (FYM) & 23.0 & 16.7 & 18.8 \\
T4=75 kg nitrogen/ha & 21.2 & 19.6 & 17.4 \\
T5=150 kg nitrogen/ha & 27.7 & 20.1 & 22.6 \\
T6=10 tonnes/h & 22.4 & 16.1 & 18.2 \\
(FYM) $+75 \mathrm{~kg} \mathrm{~N} / \mathrm{ha}$ & & & \\
T7=10 tonnes/h & 30.4 & 21.9 & 24.9 \\
(FYM) $+150 \mathrm{~kg}$ N/ha & & & \\
T8=20 tonnes/ha & 25.5 & 18.3 & 21.0 \\
(FYM) $+75 \mathrm{~kg}$ N/ha & & & \\
T9=20 tonnes/ha & 24.5 & 17.6 & 20.2 \\
(FYM) $+150 \mathrm{~kg}$ N/ha & & & \\
$\quad$ LSD between cultivars \\
$\quad$
\end{tabular}

The main objective of agronomical research concerning any crop is to identify the experimental treatments best affecting yield, from sowing to harvest. Among the major factors, such as environmental conditions, genetic makeup, soil structure and cropping management, the type of nitrogen supplied exerts variable influence based on plant species (Caruso et al., 2011). Notably, potato plant growth and yield is significantly affected by the application of nitrogen (Blumenthal, 2004; AbouHussein et al., 2003), since potato plants need large amount of available nitrogen in the soil for proper phenological development, yield and tuber quality (Westermann and Kleinkopf, 1985). Our results demonstrated that the maximum tuber yield per ha was obtained in T7, associated with the application of $10 \mathrm{t} / \mathrm{haFYM}$ $+150 \mathrm{~kg} / \mathrm{ha} \mathrm{N}$, which has presumably provided the plants with suitable growing conditions, i.e. soil fertility status. Interestingly, further nitrogen application increase with FYM resulted in reduced tuber yield.

\section{Conclusion}

Overall results obtained from a research carried out in Gilgit-Baltistan (Pakistan) revealed that the application of $10 \mathrm{t} / \mathrm{ha}$ of farmyard manure $+150 \mathrm{~kg} / \mathrm{ha}$ of mineral nitrogen led to the most beneficial effect on potato tuber yield, among the three red skinned potato cultivars tested, Desiree showed the best performance. Though the results may differ depending on the location where potato is grown, the opportunity of supplying manure as a fraction of the whole crop nitrogen requirements makes the nutrient management easier and cheaper for farmers.

\section{References}

Abou-Hussein, S.D., El-Shorbagy, T., Abou-Hadid, A.F., El- Behairy, U. 2003. Effect of cattle and chicken manure with or without mineral fertilizers on tuber quality and yield of potato crops. ISHS Acta Horticultural, 608: 95-100.

Allison, M.F., Fowler, J.H., Allen, E.J. 1999. The nutrition of the potato crop. British Potato Council Research Report 807/182. 92 p.

Akhtar, P., Abbas, S.J., Aziz, M., Shah, A.H., Ali, N. 2010. Effect of growth behavior of potato mini tubers on quality of seed potatoes as influenced by different cultivars. Pakistan Journal of Plant Science, 16: 1-9.

Alam, M.N., Jahan, M.S., Ali, M.K., Islam, M.S., Khandaker, S.M. 2007. Effect of vermicompost and NPKS fertilizers on growth, yield and yield components of red amaranth. Australian Journal of Basic and Applied Sciences, 1: 706-716.

FAO, 2010. FAOSTAT -Agriculture, http:// faostat. fao.org/ site/339/default.aspx.

MINFAL, 2005. Agriculture Statistics of Pakistan. Govt. of Pakistan, Ministry of Food, Agricultural and Livestock. Economy Wing, Islamabad, Pakistan.

Benke, M.B., Hao, X., Chang, C. 2009. Effects of Longterm Cattle Manure Applications on Soil, Water, and Crops: Implications for Animal and Human Health. In: Development and Uses of Biofortified Agricultural Products, G. S. Bañuelos and Z. Q. Lin (eds.) pp. 135-153, CRC Press, FL, USA.

Blumenthal, J.M., Baltensperger, D.D., Cassman, K.G., Mason, S.C., Plavlista, A.D. 2004. Importance and effect of nitrogen on crop quality and health. In: Nitrogen in the Environment: Sources, Problems, R. F. Follett and J. L. Hatfield (eds.), pp. 45-65, Amsterdam, The Netherlands.

Caruso, G., Carputo, D., Conti, S., Borrelli, C., Maddaluno, P., Frusciante, L. 2013. Effect of mulching and plant density on out of season organic potato growth, yield and quality. Advances in Horticultural Science, 27: 115-121.

Caruso, G., Conti, S., LaRocca, G. 2011. Influence of crop cycle and nitrogen fertilizer form on yield and nitrate content in different species of vegetables. Advances in Horticultural Science, 25: 81-89. 
Chan, S. 1999. Integrated nutrients management for sustaining crop productivity and soil fertility in Japanese mint (Mentha arvensis L.) based cropping system. Thesis submitted to Dr. B.R. Ambedkar, Unversity, Agra, India.

Chattopadhyay, A., Gupta, N. 1999. Integrated nutrients management in menthol mint cultivation utilizing mint residue fertilizer. Journal of Medicinal and Aromatic Plant Science, 21: 1058-1063.

Delden, A.V. 2001. Yield and growth components of potato and wheat under organic nitrogen management. Agronomy Journal, 93: 1370-1385.

Gruber, H., Thamm, U., Michel, V. 2003. Effective use of legume nitrogen in the crop rotation. Ökol Landbau, 127: 29-31.

Hopkins, W.G. 1997. The essential nutrients elements: Introduction to Plant Physiology. pp. 68-73, John Willey and Sons. Inc. Pub., USA.

Joern, B., Vitosh, M.L. 1995. Influence of applied nitrogen on potato, Part I: Yield, quality and nitrogen uptake. American Journal of Potato Research, 72: 51-63.

Najm, A., Hadi, H.S., Fazeli, F., Darzi, M.T., Shamorady, R. 2010. Effect of utilization of organic and inorganic nitrogen source on the potato shoots dry matter, leaf area index and plant height, during middle stage of growth. International Journal of Agriculture and Biosciences, 1: 26-29.

Patra, D.D., Anwar, M., Chand, S. 2000. Integrated nutrient management and waste recycling for restoring soil fertility and productivity in Japanese mint (Mentha arvensis) and mustard (Brassica juncea) sequence in Utter Pardesh, India. Agriculture, Ecosystems \& Environment, 80: 267-275.

Perrenoud, S. 1983. Potato-Fertilizers for yield and quality. International Potash Institute Bulletin, No. 8, p. 84, Berne, Switzerland.

Rehman, L. 1996. Effect of mulch different manures and fertilizers. M.S Thesis. Department of Horticulture, pp. 45-48, Bangladesh Agriculture University, Mymensingh-2202, Bangladesh.

Steel, R.G.D., Torrie, J.H., Dickey, D.A. 1997. Principles and Procedures of Statistics. A Biometrical Approach. $3^{\text {rd }}$ edition, pp. 172-177, McGraw Hill Book Co. Inc., New York, USA.

Tuku, B. 2000. Potato production in Eritrea: Prospects for future development. Proceedings of the $10^{\text {th }}$ Triennial Congress of African Potato Association. Kampala, Uganda. P. 15-16

Westermannn, D.T., Kleinkopf, G.E. 1985. Nitrogen requirements of potatoes. Agronomy Journal, 77: 616-621. 